\begin{tabular}{|l|l|l||}
\hline \multicolumn{2}{|c|}{ PublisherInfo } \\
\hline \hline PublisherName & $:$ & BioMed Central \\
\hline \hline PublisherLocation & $:$ & London \\
\hline \hline PublisherImprintName & $:$ & BioMed Central \\
\hline \hline
\end{tabular}

\title{
Morphine potentiates salmonella infection
}

\begin{tabular}{|l|l|l||}
\hline \multicolumn{2}{|c||}{ ArticleInfo } \\
\hline \hline ArticleID & $:$ & 4200 \\
\hline \hline ArticleDOI & $:$ & $10.1186 /$ ccf-2000-5338 \\
\hline \hline ArticleCitationID & $:$ & 5338 \\
\hline \hline ArticleSequenceNumber & $:$ & 59 \\
\hline \hline ArticleCategory & $:$ & Paper Report \\
\hline \hline ArticleFirstPage & $:$ & 1 \\
\hline \hline ArticleLastPage & $:$ & 3 \\
\hline \hline & & RegistrationDate : 2000-6-4 \\
ArticleHistory & $:$ & OnlineDate \\
\hline \hline ArticleCopyright & $:$ & Current Science Ltd2000-4 \\
\hline \hline ArticleGrants & $:$ & \\
\hline \hline ArticleContext & $:$ & 1305422 \\
\hline \hline
\end{tabular}




\section{Keywords}

Analgesics, immune response, infection, morphine

\section{Comments}

This animal study showed that implantation of subcutaneous morphine dramatically reduced survival and increased bacterial burden. This effect appears to be mediated via opiate receptors. Although the dose appears large, the steady state plasma levels obtained are within the analgesic range for the drug $(0.6 \mu \mathrm{g}$ per $\mathrm{ml})$. The timing of the morphine dose seems to be important, with worsened outcome if bacteria and morphine are given simultaneously. Naltrexone extended the mean survival time (MST), and blocked colonisation of salmonellae yet did not reduce mortality. The authors hypothesise that this may be due to the fact that naltrexone is a competitive antagonist and endogenous opiates would reduce its effectiveness. The increase in mortality may be due to slowing of the gastrointestinal transist time, or increased gut permeability (for which there is some experimental evidence). This study, albeit in an animal model, supports other animal data that morphineis immunosuppressive and hence has important implications for ICU patients, post operative patients and IV drug abusers.

\section{Introduction}

Animal data exist to suggest that opiates may be immunosuppresant. This is seen clinically in IV drug abusers who are predisposed to a variety of opportunistic infections. This animal study looked at the responses of mice innoculated with Salmonella typhimurium following varying doses of morphine or morphine and naltrexone.

\section{Methods}

- 6 week old female mice were used. 
- Salmonella typhimuriumwas prepared from a human source and innoculated orally

- 5 groups given $75 \mathrm{mg}$ morphine pellet, between $16 \mathrm{mg}$ to $75 \mathrm{mg}$ morphine, $30 \mathrm{mg}$ naltrexone pellet, morphine and naltrexone and placebo pellet.

- All pellets were administered subcutaneously.

- A sample of animals were killed at predetermined times and Peyers patches, spleen and mesenteric lymph nodes analysed for bacterial burden.

- Groups of animals were observed daily and mortality recorded for up to 40 days

- Other groups, as above, were killed at $40 \mathrm{~h}$ and mRNA levels of cytokines determined.

\section{Results}

Morphine $75 \mathrm{mg}$ pellets dramatically increased lethality and decreased MST. Treatment with naltrexone plus morphine increased MST from 3.2 to 11.6 days. All doses of morphine resulted in a $100 \%$ mortality at 9 days versus $50 \%$ in the placebo group, although there was a significantly increased MST in the low dose morphine group $(16 \mathrm{mg})$. When the bacterial counts of 45 samples from animals receiving naltrexone were analysed, only three had culturable levels of the organism whereas all samples from animals receiving morphine had culturable amounts. There was a $10^{6}$ increase in bacterial burden in the Peyers patches of mice receiving morphine. On the basis of median bacterial burdens naltrexone partially blocked the effect of morphine in the spleen, liver and mesenteric lymph nodes, and completely blocked it in Peyers patches. Giving morphine 24-48 h before or after innoculation increased MST. iNOS and TNF- $\alpha$ mRNA levels were significantly enhanced in the morphine group and this effect was antagonised by naltrexone.

\section{References}

1. MacFarlane AS, Peng X, Meissler JJ, Rogers TJ, Geller EB, Adler MW, Eisenstein TK: Morphine increases susceptibility to oral salmonella typhimurium infection. J Infect Dis. 2000, 181: 1350-1358.

This PDF file was created after publication. 